\title{
JOSEPH OF ARIMATHEA, THE HOLY GRAIL, AND THE EDESSA ICON
}

By Dr Dan Scavone, retired professor of History at the University of Southern Indiana.

This article was first published in Arthuriana, Vol. 9, no. 4, Winter 1999, pp. 331. A chronological list of supporting texts has had to be omitted from this newsletter, but will be published in number 57, next June.

Evidence that the Grail legends begun with Robert de Boron were inspired by Byzantine apocryphal texts and the rituals associated with the Edessan burial shroud icon. Joseph is the common link between apocrypha and Grail.

Scholarly opinions have seen the origins of the Grail in magical life-giving and food-providing stones, cauldrons, and dishes. These have been traced to distant Persian, Alan/Sarmatian, or Ethiopic legend or to nearby Celtic lore. It is amazing how many schools of interpretation are possible, all from plausible readings of the medieval Grail sources. Pagan Celtic resonances, e.g., have been especially well demonstrated.1

My thesis addresses only the possible origins of the Christian or Holy Grail. It falls essentially in the "Byzantine school" of Grail interpretation.2 But it does not purport to take issue with the Grail's possible Jungian ties to other mythologies. It introduces into the mix the famous Mandylion or Christ-icon of Edessa (modern Urfa in southern Turkey). Specific documents and rituals surrounding the Mandylion resonate closely with and provide precise sources for the chief attributes of the Holy Grail.

Like the legendary Holy Grail, this cloth was linked to Joseph of Arimathea, resided in a place known as Britium, was thought to have contained Jesus' body, captured Jesus' dripping blood on Golgotha, and was displayed only rarely and in a gradual series of manifestations from Christ-child to crucified Jesus. The sources clearly originate in the Byzantine East, and their presence in the Grail romances is precisely concomitant with the presence of numerous Westerners in the East.

Most Grail scholars agree that the Christian Grail legend was first fully developed in Robert de Boron's Roman de l'Estoire dou Graal (or Joseph). Robert's seminal version tying the Grail to the Last Supper was subsequently elaborated in the longer redactions of the First Continuation of Chrétien de Troyes, the Perlesvaus, and several Branches of the Vulgate, especially the Queste and the Estoire. During the course of my discussion, I shall also suggest the source of the misunderstandings by which Joseph of Arimathea could be accepted by medieval writers as an apostle to Britain. My argument is essentially literary, proceeding by comparisons of the Grail's attributes in Grail romances with those of the Edessa icon in its literature and iconography. Of course, the reader should not construe a literal identification of icon and Grail.

\section{THE EDESSA ICON}

The icon, often called the Mandylion, was as confusing to its contemporaries as the Grail was to its romancers. Thought for centuries to be a cloth-borne image of the face of Jesus, the Edessa face icon was hinted already in the sixth century to be a much larger object and noticed in the tenth century to contain blood in the areas where Jesus must have sustained wounds. In one of its early rituals in Edessa before 944 and possibly in Constantinople from 944 until it was lost in 1204, it was unfolded to suggest 
first the infant Jesus and then, by a gradual series of changes throughout the day, the crucified Jesus. I will detail these rituals later in my discussion.

The earliest full account of the icon, the fourth-century Syriac Teaching of Addai, describes it as a painting of Jesus' face made from life during his ministry by Hanan, an agent of ailing King Abgar V of Edessa (13-50 CE). Remarkably, the anonymous author comments on the "choice paints" used by Hanan, while omitting mention of the medium, whether wood, parchment, or cloth. According to this account, Abgar was healed by the painting and became a Christian.

All subsequent texts, however, consider the icon to be a large cloth, and miraculously made. The usual Greek descriptor for this, (acheiropoietos), "not made by human hands," was first suggested by the historian Evagrius, writing in the late sixth century. The Acts of Thaddaeus (Greek for Addai already in the version of Eusebius, who did not mention the icon) was a major retelling of the Abgar legend. Though its earliest MS dates from the ninth century, it is thought to derive from a sixth-century original. The anonymous author of this account says the brill iance surrounding Jesus' face prevented Abgar's messenger from achieving the portrait, so Jesus wiped his face on a tetradiplon and left its impression on "this sindon." Tetradiplon is no word for towel; it suggests a cloth seen folded in eight layers. Sindon is the NT synoptic word for Jesus' burial cloth.3 Whether this divergence from the Teaching of Addai is a matter of a deliberate literary enhancement of a Jesus icon or a case of a gradually growing awareness of its true aspect and size, we are presented here with antiquity's initial point of confusion about this icon. 4

On August 15, 944, the icon was transferred from Edessa to Constantinople. There, as in Edessa, it continued to be held as sacred and was rarely approached. Still, in the Byzantine capital it inevitably found more viewers--and more rumoured opinions about it. From this time too, a number of painted reproductions show that it was kept folded-recall tetradiplon--in a rectangular case and overlaid by a latticework decoration more or less typical of Byzantine icons, with only the face visible in a central circular aperture. 5

The icon's arrival in Constantinople was celebrated by processions and ceremonies. It was then placed in the Pharos Chapel, the imperial relic treasury located in the Bucoleon palace. At least two eyewitness accounts relate the events of that day. Soon after its arrival, the first account, the Narratio de imagine Edessena, an important text produced under the auspices of Constantine VII Porphyrogenitus (913-959), retold the Abgar story and described the facial image as extremely faint, more like a "moist secretion without pigment or the painter's art." It is the third major text--the Teaching of Addai and the Acts of Thaddaeus being the other two-that comments on the strangeness of the image. All three explain it differently. This third description, virtually confirming the first two, but with believable details available only to an eyewitness, permits an assumption that the author is looking at the same icon as were the anonymi of the Teaching of Addai and the Acts of Thaddaeus.

The Narratio adds a remarkable variant to the original Abgar story, one preferred by its author, who sets the creation of the image now in the Garden of Gethsemane:

There is another version: . . . When Christ was about to go voluntarily to death, sweat dripped from him like drops of blood. Then ... he took this piece of cloth which we see now $\ldots$ and wiped the drops of sweat on it. 
This gratuitous variation is inexplicable, unless traces of blood were seen on the face. The Narratio continues:

[In Edessa] Abgar alone could see the unbearable brightness shining from the portrait that Thaddaeus had placed on his forehead. Forgetting the long paralysis of his legs he leapt up from his bed and ran to meet Thaddaeus. 6

The healing of the king's legs and the unbearable brightness of the icon may call to mind identical elements surrounding the Grail in its twelfth- and thirteenth-century romances.

The second, also contemporary, eyewitness account is an autograph sermon of Gregory, archdeacon and referendarius of Hagia Sophia, dated August 16, 944, the day after the icon's arrival. Gregory seems to have "chaired" the committee of clerics assigned to plan for the reception of the icon in the capital. He may actually have held it in his hands. Most significantly, Gregory suggested, but with some vagueness, that this icon of Jesus' face showed a wound in the side. He tells us:

[This image] was imprinted only by the perspiration of the agony running down the face of the Author of Life.... And ... has been embellished by the drops from his own side... . Blood and water there, and here the perspiration and figure. ... The image and [that] which made the side to bleed were of the same nature that formed the portrait.7

These two eyewitness narratives divulged that the icon was not-and had never been--a relic of Jesus' ministry, but of his Passion. Yet Gregory, as others before and after, under the spell of the original Abgar accounts, seems not to have understood the import of his own observations. Though the facial bloodstains conjured up his reference to Gethsemane, Gregory never referred to the cloth as a burial-cloth icon.

Why were the bloodstains and full body on the icon not immediately noticed? Why this confusion about the visual contents of the cloth? In its legends (Evagrius, n. 3 ), the icon had for centuries been kept folded and hidden away in treasuries and sealed inside Edessa's city wall. Descriptions of its Edessan rituals indicate that it had been shown to the masses only rarely and amidst mysterious ritual. Thus there were few individuals who had personally experienced it. So secretly was this icon kept that, as with the Grail, its true nature was not precisely known. As the Grail accounts differ from one another regarding its "whatness," so also do the terms used by Greeks or Westerners for this icon differ. In texts we find mandylion, mantile, sancta toella, imago, linteum, manutergium, ektypoma, tetradiplon, sindon, soudarion, and the plurals spargana, panni, fasciae, othonai, sindones--and the list is not exhaustive. 8

Moreover, the icon held a secret, as suggested by Gregory's sermon and fortified by texts yet to be discussed. Folded behind the face was a full-length impression of Jesus' body, complete with the side wound of the crucifixion: the facial icon was really a buriatshroud icon. In its infrequent displays and rituals, the Edessan clergy displayed the icon amidst a deliberate mystique of secrecy vis-à-vis the congregation. Western travellers and crusaders in the Near East may reflect a confusion born of this secrecy and the icon's multiple terminology. Though they heard whisper of something intimately identified with or "containing" the portrait or the body and blood of Jesus himself, the object's true nature was unclear and, under the enhancing power of rumour, their reports may have led to the creation of different descriptions of the Grail.

A Greek text of 960 is instructive regarding this ritual secrecy. Once a year, it says, the archbishop entered alone the room of the icon: 
The old chest was encased with shutters, so that it would not be visible to all whenever they wished. . . . These shutters were opened by means of iron rods that were thrust through. . . . [Only] then could the congregation gaze upon it. . . . But nobody was allowed to draw near to it. ... Thus holy dread increased their faith, and made them shiver with yet more awe in their worship. 9

The most striking description of one of the icon's rituals, the so-called "Oldest Latin Abgar Legend," also possibly tenth century, virtually claims to be a translation from an Edessan original. It states explicitly that the image was of Jesus' full body and was never shown to the faithful close-up. This text asserts that while still in Edessa, the icon was kept in a gold chest (scrinium) and

... on Easter it used to change its appearance according to different ages: it showed itself in infancy at the first hour of the day, childhood at the third hour, adolescence at the sixth hour, and the fullness of age at the ninth hour, when the Son of God came to His Passion ... and ... cross. 10

Whatever the meaning or method of effecting these changes, a gradual and mysterious revelation seems to be the intent. As is well known, the alternation between Christ-child and crucified Jesus lies at the heart of the secret of the Holy Grail when it is achieved by the worthiest knights in the thirteenth-century French Grail romances, particularly in the Perlesvaus and Vulgate Queste.

A thirteenth-century MS, copy of an earlier Armenian version of the Abgar legend, may shed light on this method of display. The author tells the Abgar story using Eusebius' chapter numbers, but unlike Eusebius, he includes the icon. Again, Abgar's artist could not paint Jesus, for at first he appeared to be thirty years of age, as he really was, but afterwards he appeared older, and finally he seemed a twelve-year-old boy. Abgar's messengers were amazed at this unusual vision of a miracle.11

Two other texts are suggestive in support of a gradual raising of a cloth bearing a full-body image such as would underlie the ritual's child-to-crucified changing display. Nicholas Mesarites, in 1201 the overseer of the imperial relic treasury in Constantinople and thus eyewitness, described the sindon in his care. "In this place the naked Lord rises again [anistatai] and ... the burial sindons can prove it [ekdelon]." 12 Two years later, Crusader Robert of Clari reported: "In the church of Our Lady of Blachernae [the Blachernae Palace being the more recent dwelling of the Byzantine emperors] the sydoines [sic: singular] of Jesus stood up straight every Friday [cascuns devenres se drechoit tous drois] so that the figure of Our Lord could be plainly seen there."13 These texts amplify, if they do not clearly confirm, the revelations of Gregory Referendarius in 944. Both Mesarites and Clari used language that suggests a raising of a folded cloth so as to reveal its secret fullness as a shroud icon of the crucified Jesus. The resonances of both with the Edessa scrinium ritual are clear. Both writers show by the perspicacity of their writings that what they described was not simply a woven epitaphios or threnos icon of Jesus on a cloth, new artistic types seen in Byzantine churches in the twelfth century and discussed below. Clari regularly distinguishes ordinary painted icons from the sydoines icon in question, and Mesarites, close enough to comment, as he does, on the quality and aromas of the burial cloth, has noted the nudity of the figure, such as was not the norm in epitaphioi or threnoi.

\section{WHY JOSEPH OF ARIMATHEA?}

Joseph of Arimathea's role in the Gospels is small. He appears suddenly on Good Friday, and after giving Jesus a shroud and a tomb, he is "written out" of the 
story. But Joseph is prominent in second- to eighth-century apocryphal texts from the Byzantine East. And from the late twelfth century, in Western Grail legends, he achieves a new prominence as the carrier of the Grail, the vessel of Jesus' blood, to the West. Geoffrey As he has properly asked, "Why Joseph?" $(1958,240)$.

Joseph's intimate association with the NT burial sheet that enclosed the body of Jesus and was stained with his blood and his later connection to the Grail establishes him as an important link, virtually compelling a consideration of the lost Edessa buriat cloth icon as that object inspiring the legends of the Holy Grail. Indeed, it may be possible to demonstrate finally from Edessan texts and history that Joseph of Arimathea never saw Britain, and certainly not with the chalice of the Last Supper.

The Byzantine Acts of Pilate, variously dated from the second to the six th century, contains the best-known early non-Biblical references to Joseph.14 Its first eleven chapters follow the Gospel accounts up to Good Friday. But from Ch. 12 on Joseph becomes the chief character: On Saturday he was seized by Jewish leaders as a Christian and locked up. But on the next day, he had mysteriously disappeared from his cell. "Opening the door, they found him not. And . . . they found the seals unbroken, and ... Caiaphas had the key." Joseph later related how angels had lifted up the prison at its four corners and how Jesus had released him and had proved his identity by showing him the linen shroud and face napkin still in the tomb. There is no reference to a Grail, but only to the NT shroud. Let us see how previously insignificant Joseph and the Edessa shroud icon may have provided the seeds that would grow into the legends of the Holy Grail.

\section{THE GRAIL}

It is impossible to discuss the Grail without rehashing a great deal of well-known previous scholarship. My hypothesis inc orporates Grail elements thus long established. One such element is the long allegorical tradition among Byzantine theologians beginning at latest with Isidor of Pelusium and Cyril of Alexandria (early 5th c.) and Maximus the Confessor (6th c.). These writers of liturgical exegeses already associated Joseph with the Eucharistic liturgy. Burdach (151-176) quotes John Chrysostom (4th c.) as a forerunner of many of their allegorical nexus. Germanos, Patriarch of Constantinople (d. 740), may have been the source for liturgist Amalarius of Metz (ca. 780-850), from whose Latin, in turn, Honorius of Autun (fl. 1130) most likely drew. It is instructive that Amalarius produced his Eclogae about 813, right after his return from a mission to Constantinople on behalf of Charlemagne. While Honorius is most commonly named for his allegorical interpretations of the Eucharistic service, all of these liturgists drew comparisons between Mass paraphernalia (e.g., altar, paten, chalice) and Jesus' Passion and burial. From Germanos on, all agreed that one of the deacons symbolized Joseph of Arimathea. But not all the identifications are alike among these exegetes. For example, Germanos made the "chalice" a symbol for the Last Supper cup. For Amalarius, the chalice symbolized the Lord's body: as the blood is in the body, so the wine is in the chalice. In the mid-twelfth century Honorius wrote that the chalice of wine and water represented the blood and water of Christ's side, while a few lines later he identified the chalice with the sepulchre.15 The allegorical method opens many doors.

My thesis supposes that the twelfth- and thirteenth-century authors of the Christian Grail romances were wonderfully creative poets who built upon a persistent legend coming to Europe--via pilgrims, prelates, merchants, and especially knightsabout a precious but not clearly comprehended object of the Byzantine East that was reputed to "contain" the body and blood of Jesus. Their disagreement about what the 
Graal was or what it was supposed to do, however, permitted them to mingle pagan and Christian definitions and attributes as the spirit moved them.

What is true is that almost suddenly, between 1097 (Capture of Edessa in the First Crusade) and 1201 (the Fourth Crusade), a number of Byzantine texts became known and used in the West. This is borne out by the obviously Byzantine apocrypha used by Robert de Boron and by the Latin Mandylion legends found in the writings of Robert's near-contemporaries Ordericus Vitalis and Gervase of Tilbury and before them by the anonymous author of the "Oldest Latin Abgar Legend."10

Certainly, many of the issues raised in this paper may conveniently be traced to the furor surrounding the question of the Real Presence (Transubstantiation) which filled the intellectual ambience in the decades just prior to that doctrine's formal definition at the Fourth Lateran Assembly of 1215. For our purposes, it matters little that already in the ninth century this theological question had been raised by Radbertus and Ratramnus, for the moment of the Grail was not the ninth century, or any other time before the late 12th c. As Maureen Fries 16 has carefully set out, the rise of Arthurian romance had its precise historical moment. So too did the rise of the Grail romances. The Real Presence debate may have contributed to the Grail's literary moment, but it was also the moment of the return of crusading veterans with fascinating stories and experiences. The themes introduced first by Robert de Boron--Joseph of Arimathea collecting the blood on Golgotha in the cup of the Last Supper, Joseph's imprisonment, the secret of the vessel divulged by Jesus himself, the healing of Vespasian by Veronica's veil and his vengeance upon Jerusalem, the Grail's inner secret of the Christchild changing into the sacrificial crucified Christ--all, even the very vocabulary and imagery of the Grail romances, derived from Byzantine legends and ritual.

It must be acknowledged as strange that certain attributes of the shroud icon should have accrued to the Grail accounts while its actuality as a cloth remained elusive. Rumours of a Jesus relic containing body and/or blood will have made more sense to one writing in the period of Transubstantiation discussions if the "container" of Jesus' blood should be a cup, while that which "contained" Jesus' body could only be, in the West, a paten with wafer.

If Chrétien's notion of the Grail as a Mass paten-with-Host was the product of his own inspired creativity, it was a great leap to transform pagan Celtic cauldrons, or even Helinand's ordinary "wide and somewhat deep dish," into this specific Grail. But Chrétien died before he could elaborate on his magnificent idea. It is, rather, in the Grail narratives which took their direction from Robert de Boron that Byzantine accounts were clearly grafted upon previously existing Welsh-Irish myths of magical cauldrons -of-plenty.

Many of the most important features of the Grail romances can be traced back to the Edessa shroud icon's literature and ritual. This may be demonstrated in the Joseph of Robert de Boron (ca. 1200).17 Whatever the Grail may have been previously, Robert recreated it as the Holy Grail, cup of the Last Supper. It is also Robert who introduced Joseph of Arimathea into the literature as its first guardian. Drawing from the Acts of Pilate (summarized above), Robert says that Pilate gave Joseph not only the body of Jesus but now also the vessel of the Last Supper containing Jesus' transubstantiated blood. Joseph then collected in it Jesus' actual blood as it dripped from his body on Golgotha (symbolic of Christ's Real Presence). Again, Robert is the first romancer to assign this feature to the Grail. His impact, therefore, was immense. Robert continues, as does his source, that Jesus visited Joseph in his cell; now, however, Jesus returned him the precious cup and told him its secrets, but did not release him. After forty years, during which the Grail alone sustained him, Joseph was freed by Vespasian, himself just 
cured of leprosy by means of Veronica's imaged cloth. The cup has taken the place of the sindon of the Acts of Pilate, but en revanche the mention of the Veronica has given us an important clue. Robert seems to have developed this latter section from the seventh-century Vindicta Salvatoris and the eighth-century Cura sanitatis Tiberii.18

Since Chrétien had left his work unfinished, several writers produced sequels. The First Continuation, about 1200, tells a most interesting story about a head of Jesus carved by Nicodem us as he remembered Jesus on the cross. But, he says, God Himself set His hand to shaping it, for it could not be made by human hands. Given the other Grail-icon connections, this standard descriptor (acheiropoietos) of the bloodstained face of the Edessa icon is evidence that the author/interpolator of the First Continuation may have been familiar, however directly or indirectly, with the icon's literature.19 Paul Imbs has suggested the processes at work in such an alternation as the transfer of Jesus' face on cloth to Nicodemus' sculptured head: the three most frequent features of what he calls the "apocryphal lie" are transposition, amplification, and contamination. The literature of the Grail provides numerous manifestations of each.

Richard O'Gorman gives the most likely etymology of the Grail as deriving from the medieval Latin gradale:

. . "by degree," "in stages," applied to a dish or platter brought to the table at various stages or servings during a meal. . . . Helinand of Froidmont [ca. 1200] wrote: 'Gradalis . . . a wide and somewhat deep dish in which expensive meats are ... placed gradatim [in stages]. . . and in everyday parlance it is called a graalz." 20

Recall the ritual in which the shroud icon was displayed, in a series of different identifications from infant Jesus to crucified Jesus. After Robert, several Grail romances describe the achievement of the Grail in terms of a series of wondrously changing visions. The introductory lines of the Perlesvaus (ca. 1191-1225) precisely echo Robert's identification of the Grail. The author, who clearly knew Robert's chalice-Grail, assumes as known that the Grail was the vessel used by Joseph to collect Jesus' dripping blood;21 in it Gawain seemed to see its great secret: a chalice changes to a child and then to the crucified Jesus. Earlier in the same romance, Arthur had a vision clearly announcing a Eucharistic connection: At Mass,

Arthur ... saw a lady call her child her father and her son ... . and offer the child to the hermit [celebrant]. . . . [Then] it seemed that the hermit was holding in his arms a man, bleeding from his side, . . . hands and feet, and crowned with thorns. . . Then . . . the man's body changed [again] into the shape of the child.22

Similarly, in the Vulgate Queste del Saint Graal(ca. 1225), at the Eucharist Josephus (=Josephes), son of Joseph of Arimathea, descended from heaven with the Grail vessel. In it he captured drops of blood from a bleeding lance. But then he took from the Grail a host. Next, a child, whose face blazed as bright as fire, descended from above and entered into the host, which Josephus replaced in the Grail. Soon Jesus, unclothed and bleeding, emerged from the Grail, administered the sacrament, and told Galahad that the Grail is the dish from which he had eaten the Paschal Lamb at the Last Supper. The gradual change from child to crucified-and unclothed--Jesus is shared by icon and Grail.23 Might it be more than a coincidence that Helinand's definition of Graal as gradalis, "in stages, "well fits the rituals associated with both Edessa's cloth icon and the Holy Grail?

The present thesis, that the Grail's essential attributes have a Byzantine provenance in a burialshroud icon known to be in Constantinople from 944 to 1204, is 
furthered by a passage in the First Continuation that seems to describe a Greek service. In the great hall of the Grail Castle, Gawain observed a procession. A priest carried in a richly bejewelled cross. "Over his alb he wore a noble tunic of precious cloth from Constantinople. After him came a great procession of canons each clad in a rich cope of silk."24

This thesis has found support in the writings of Byzantine scholars Hans Belting and Christopher Walter. Always bearing in mind the icon's ritual of display, somehow being gradually unfolded to appear to stand up until it vividly revealed the Christ of the Passion and Cross, as the texts of Clari and Mesarites further imply, we may now add, with Belting, that the burial-cloth icon in Constantinople may have inspired new art, new texts, and even entire services, roughly contemporary with Clari and Mesarites. Belting has defined these innovations as productive of or reflecting a desire for "psychological realism." He has identified in twelfth-century Byzantium "a new iconographic theme" in which Jesus, still dead, is depicted emerging from the tomb upright with still-bleeding side wound and crossed hands bearing the nail wounds. Apropos of the present argument, the body is shown naked or nearly so, and only from the waist up, as if in the process of full revelation. Belting is explicit that this "Man of Pity" is a theme unconnected with any known event in the Gospel Passion narratives.25

The cloth threnoi-illustrations of a full-length Jesus in burial pose, seen on large cloths from the eleventh century on-were, according to Belting, accompanied by a liturgical innovation, a threnos office, "reflecting the same new mood of empathetic involvement of congregations in the suffering of Jesus. Belting further noted that the epitaphios - woven image on cloth of a gorgeously adorned full-length dead Christ, introduced around the turn of the thirteenth century--"makes no sense when studied on the basis of the biblical text alone." It sometimes took the place of the traditional veil which covered the Eucharistic bread and wine. Together, these artistic motifs manifest "a new language of Church art," one in which Eucharistic symbolism was combined with Passion realism.26 In the absence of clear reasons for these new elements of Byzantine art and ritual, it is entirely likely, given their subject matter, that the presence of the bloodied shroud icon provides a needed explanation. If so, one wishes the shroud icon, that prototypal Mandylion, had survived the Fourth Crusade, for it must indeed have been convincingly real--for all its strange unpainted appearance--and poignantly moving.

Walter and Belting also notice that in the second half of the twelfth century, the Melismos ritual first appeared in wall-painting. The fully developed twelfth-century Melismos referred to the dividing of the Eucharistic bread on the paten. In artistic representations, the earliest extant being that on a wall of the church at Kurbinovo (Macedonia) about 1191, the bread was presented visually as the naked Christ-child lying on the paten and cut up (melizetai), sometimes with a diminutive lance (longche). The child thus becomes the Sacrificial Lamb, the crucified Christ, in the distribution of Communion.27 The Melismos ritual and the epitaphios and threnos textiles all make more visible the sacrificial host--the Melismos in the form of the Christ-child, the latter two in that of the enshrouded Christ. Belting notes that the coincidence in time of all these innovations still remains unexplained. Byzantine scholars often do not know with certainty all the origins of their liturgy or iconography. These seem chronologically, textually, and visually to have been inspired by Edessa's cloth icon. As Belting has put it:

It may be no accident that, again, it is at the end of the twelfth century that we first hear of the regular display of the Holy Shroud in the church of Blachernae [text of Robert of Clari]. 
It is at the same moment that the plain veil adopted its own image [epitaphios] and the Melismos scene found its way into wall-painting. 28

Cogently evidencing the dependence of the Grail's characteristics upon a Byzantine source-the chief thrust of the present argument--are the crucial lines found in the Vulgate Estoire. The Lord has just installed Josephes, son of Joseph of Arimathea, as Christianity's first bishop. Christ then instructs him on the celebration of the first Mass, ordering Josephes to cut the child which he finds in his hands into three pieces and to swallow them. It seems clearly an echo of the Byzantine Melismos Eucharistic service in which the Christ-child is dissected in either three or four pieces to become the sacrificial victim of the cross in communion.29

Helinand's gradalis etymology of the word Graal thus fits all of these nuances. The Grail's secret as revealed to the best knight of the moment was the sequence by which the Christ-child changes into the crucified Jesus. This most essential element found in several Grail narratives strikingly recalls Helinand's Grail etymology and resonates the processional ritual in the romances and the rituals of the Edessa/Constantinople shroud icon.

In the Greek world the icon seems to have inspired the Melismos ritual and the threnos and epitaphios art. Can it have also inspired the literature of the Grail? As an object reputed in its day to somehow contain the actual body--and the actual blood-of Christ, it was so awesome that in the East it was not openly discussed and was displayed rarely and in a manner deliberately confusing to the faithful, and in the West its secret could not be divulged and could be achieved only by a knight totally free of sin. Can the Grail, a purely literary existent, and the once really existing icon be two expressions of the same object?

\section{SYNTHESIS I: JOSEPH OF ARIMATHEA IN BRITAIN}

Chrétien never mentioned Joseph. Robert did not bring Joseph westward. Rather Bron, now called the Fisher King, went west with the Holy Grail. The literary pathways by which Joseph was brought westward with the Grail in the romances are as treacherous as the Sword Bridge. The following texts, taken as a whole, may well provide the solution to Joseph's hardly credible literary journey to sainthood in Britain.

A 5th-8th c. early "I, Joseph" Georgian text, crucial for my thesis, contains probably the first notice that Joseph's apocryphal missionary activity was associated with that of St. Philip and that together the two built a church at Lydda (Diospolis), directly west of Jerusalem.30 The NT Book of Acts names two Philips and defines their missionary area as Samaria and Caesarea in Palestine and Hierapolis and Phrygia/Galatia in Turkey. If Joseph had ever been associated with Philip, primary documents place them only in the East.31 The reader is asked to keep this point in abeyance.

A literary floodgate was opened by an anonymous monk who, about 530, was copying the Liber Pontificalis, a chronicle of the popes listing salient events during each reign. Under Pope Eleutherus (170-185), the copyist inserted: "This pope received a letter from British King Lucius [Britannio rege Lucio] asking that he might be made a Christian through his agency." The copyist did not name Philip or Joseph. The problem is that in 170 there were no kings of Britannia, which was still a Roman province. Both l'Abbé L. Duchesne, premier editor of the Liber Pontificalis, and Louise Ropes Loomis, its translator, wonder about the source of the insertion. Loomis asserts that the "statement . . . appears first here in Liber Pontificalis."32 
The interpolated note was used by Bede (8th c.) in his Ecclesiastical History of Britain, who in turn was a source for every other early British historian, including Pseudo-Nennius. Bede followed his source in naming British King Lucius and Pope Eleutherus, and he accepted the first conversion of Britain at that time.33 Gildas, sixthcentury monk-historian, our earliest British source--and Bede's main authority--made no reference to any of this.34 Thus Bede's source here must be the scribal insert. But this simple insertion has had the most far-reaching consequences.

William of Malmesbury, writing his history of Glastonbury Abbey about 1125, used Bede and Freculphus, ninth-century bishop of Lisieux. The words of Freculphus' Chronicle: Phillipus . . . Gallis praedicavit Christum 35 were ambiguous enough to suggest that Philip had preached in France rather than--what was true--among the Gauls in Galatia, Turkey. Indeed, William's original book had said only that unnamed missionaries had been sent to Britain by the pope at the request of British King Lucius in 166 (from Bede). He said that if St. Philip had preached in Gaul "as Freculphus had declared," it was probably he who sent the missionaries into Britain. Though William did not mention Joseph, his book led ultimately to the claims of Glastonbury Abbey to have been founded by Joseph of Arimathea.

The little book by J. A. Robinson, essentially the locus classicus on this topic, tells what happened next, and it is well known. In 1184 fire had seriously damaged Glastonbury. Funds were required for its repair. In 1189 funding from King Henry II ceased with his death. In 1191 the monks announced that they had found the bodies of King Arthur and Guenevere on the grounds, and soon after they claimed the tomb of Joseph with two vials containing the blood and water from Jesus' side. The tourists came with open purses.36 But two vials are not the Grail--which, oddly, Glastonbury never claimed to have.

In 1247 William's book was copied by Glastonbury monks --with additions. In a new introduction we read, "St. Philip was [emphasis added] in Gaul, as Freculphus tells us. He sent twelve disciples to preach in Britain, and as is said [ut ferunt], he placed at their head his favourite disciple, Joseph of Arimathea." It is this derivative text of 1247 that first directly placed Joseph in Glastonbury and it derives from Freculphus, the sixth-century insertion (via Bede), and the Georgian MS linking Joseph with Philip. Wesselofsky and Imbs think the old Lydda tradition of Joseph and Philip as missionaries and their construction of a church to the Virgin was adopted and adapted by Glastonbury. In adding the character of Joseph, the Glastonbury redactors, of course, had the motive of placing him in Glastonbury and making it the primal seat of the Faith in Britain.37

\section{SYNTHESIS II: WHO IS KING LUCIUS OF BRITAIN?}

Biblical scholar Adolf Harnack first noticed in 1904 that the interpolated King Lucius in the Liber Pontificalis was really King Abgar VIII, full name Lucius Aelius [Aurelius] Septimius Megas Abgarus VIII (177-212), first Christian king of Edessa and the only King Lucius who espoused Christianity in the late second century, time of Pope Eleutherus.38 Harnack also revealed the crucial fact that Edessa was sometimes referred to by a term describing its citadel: in Syriac Birtha, in Latin Britium. The sixth-century Syriac Chronicle of Edessa announces that "in the year 205 Abgar VIII built the Birtha."39 Clement of Alexa ndria, late second century, fortifies this identification: a Latin excerpt of his fragmentary Hypotyposes (Themes) says the tomb of St. Jude-Thaddaeus was known to be in Britio Edessenorum, the citadel of Abgar.40

Palut, Edessa's first bishop, was consecrated around 200. The Chronicle of Edessa mentions the destruction by flooding of "the sanctuary of the Christian church" 
in 201.41 Eusebius notes that the bishops of Phrygia and Osrhoëne (of which Edessa was the capital) communicated with the bishop of Rome in the time of Pope Eleutherus.42 Ample documents assert that Abgar VIII had close ties with Rome.43 Rome's client kings sometimes took Roman names, and Abgar likely took his from Emperor Septimius Severus.44 Around 202, on Septimius' invitation, Abgar visited Rome amid a lavish reception.45 So new convert Lucius Abgar may indeed have corresponded with Eleutherus--Lucius of Edessa, not England. The "British King Lucius" of the sixth-century insert in the Liber Pontificalis fits England not at all, and Edessa entirely.

\section{SUMMARY AND CONCLUSION}

The links of my hypothesis are in place. Edessa possessed from the fourth century a cloth icon of Jesus' face (attested by artists' copies), later verified as a lifesized icon of his body. It had beenfolded and encased so as to reveal only his face, in essence disguised, and later hidden away. Lucius Abgar VIII (177-212), first Christian king of Edessa and in touch with Rome, may have received it (I won't insist on this), along with the missionaries he himself requested (letter of King Lucius to Pope Eleutherus). In the fourth century it was given a fabricated aetiology as a face-only icon that had arrived in Edessa in the first century (Teaching of Addai). From the sixth century on, it was suggeste $d$, then eye-witnessed, as larger and gradually documented as Jesus' burial cloth. The burial cloth of Good Friday was intimately associated with Joseph of Arimathea. The object in question at the time the Grail romances were written was somehow known to be associated with Joseph.

Meanwhile, in the West a scribal insert began Joseph's new career, which ultimately transported him to "Britain"--really Britio Edessenorum, place of the shroud icon--with an object known as the Holy Grail. The two objects share significant virtually identical properties. The cloth is unique among Byzantine icons as the Holy Grail is unique. All the links would indicate that the key elements of the Grail romances derive from Byzantine sources, particularly those that relate to Edessa's icon, the Mandylion.

Let us consider the Grail's secret from the point of view of a medieval Christian. As cup of the Last Supper and container of the blood of Jesus, believed to be God incarnate, it is already so awesome as not to require the embellishment of some further, anticlimactic secret. So why a secret in the first place? It only makes sense if the Grail, alias the Mandylion, truly contained a further mystery in the revelation of its real contents: the gradually appearing body of crucified Jesus of the Mandylion's ritual.

Finally, that eighth-century Georgian manuscript --it antedates by centuries every Christian Grail narrative --may alone contain the truth: Par. 16 says, "I [Joseph] climbed Holy Golgotha, where the Lord's Cross stood, and I collected in . . . the large shroud the precious blood that had flowed from His holy side."46 Please see again Robert de Boron's version of this event, which simply substitutes the Grail for the shroud.

In the apocryphal tradition about Joseph of Arimathea, then, before Joseph's Holy Grail as cup of Jesus' blood, there was Joseph's cloth in which he had captured the blood of Golgotha. Britium's face icon (Mandylion) was over time identified as a burial shroud icon of the body of crucified Jesus. The mysterious tenth-century ritual in Britium/Edessa and the new twelfth-century Byzantine Melismos service, inspired respectively by the presence of this reputed burial wrap, portrayed the infant Jesus becoming the adult Jesus, sacrificial victim of the Last Supper and Passion. The romance Holy Grail also revealed the mystery of the infant Jesus changing to the body of crucified Jesus. 


\author{
Was this the secret of the Holy Grail? Was the Grail's secret the Mandylion's \\ secret?
}

\title{
ENDNOTES
}

This paper owes much to the seminal work on the Edessa icon done by Ian Wilson and by Vanderbilt University historian Robert Drews. I do not, however, enter issues relating to the Turin Shroud, but limit all discussion to the icon alone. Warmest thanks go to Elizabeth Sklar, Norris Lacy, and Norman Hinton for their valued suggestions. I also wish to thank Fr. Maurus Green and Fr. Albert Dreisbach for their well-researched insights and especially the latter for sending me a short article by Terence Towers which set me on the course of this research.

1 For the Alans, see Littleton. For Ethiopia, see Adolf. For the classic Celtic interpretation, see Bromwich and, for convincing Celtic resonances, Loomis (1963), especially 79, 158-160, and passim.

2 E.g., Bruce, I. 257-258, n. 1, cited Burdach for the notion that the Grail emerged from "a description of the Byzantine mass which some crusader had brought home." Burdach focused his attention on the Eastern legends of the Lance of Longinus. Edessa was not in his vocabulary. H. and R. Kahane, Wesselofsky, and Zambon present similar Byzantine approaches but have not noted the texts relating to the Edessa icon.

3 See Howard, 3-13, and Roberts, "Acts of the Holy Apostle Thaddaeus," VIII. 558, esp. n. 4. Greek in Dobschütz, 182*, a basic work for my discussion of the Edessa icon. His volume has a triple pagination: $1,1^{*}, 1^{* *}$. Eusebius (d. 339) H.E. I.13 is the best-known source for the story of the healing of Abgar. A proto-iconoclast, he introduces a healing letter from Jesus but no icon. Drijvers, however, has suggested that the Syriac Teaching of Addai may antedate Eusebius' version.

The expression of Evagrius (fl. 597) H.E. 4.27 in Dobschütz, 68** and 70**, is not but "God made without human hands." Cameron argued that since Procopius (fl. 527-565) did not seem to know about the icon in Edessa, it did not exist as a miraculous icon in his day but only assumed this stature after Procopius wrote. This opinion is consonant with the hypothesis of this paper. In its earliest version the Edessa icon was indeed called merely and not remarkably a human artifact. Focusing on Abgar V, Procopius, however, did not seem to know of the arrival of Christianity as late as the time of Abgar VIII. Moreover, his account of Augaros (Abgar) is highly anecdotal in its own right. For this early period he is not the final arbiter Cameron would make him. Cameron is correct in arguing that Procopius' omission of the icon is not in imitation of Eusebius, since Procopius obviously used other sources. But neither did he seem to know the earliest text of the icon, the Teaching of Addai. So we may agree with Runciman, who thought Procopius simply did not know of the icon.

4 Debate on the size of this cloth icon hinges on its sometime name, Mandylion. This word, it is argued, is related to Arabic mandil, "kerchief." But it is clear that the earlier terms used for the Edessa icon, sindon and tetradiplon, seem to describe a larger cloth. While it is true that sindon can denote a generic linen garment, in its association with Jesus it always means "burial shroud." Mandylion, therefore, is not the original term; its usage begins only about 990, and it is derivative. See also n. 7 below.

5 The manner in which the Mandylion was encased is verified by pictorial examples from the tenth to the thirteenth centuries, the earliest perhaps being that in the apse of the Sakli church in Cappadocia. See Wilson (1986), color plate 28; also Bulst, illustrations 118, 119, 121, and 122. My project does not address Wilson's and Bulst-Pfeiffer's views on the Turin Shroud but only their contributions regarding the Edessa icon.

6 Constantine VII Porphyrogenitus, de imagine Edessena, in Dobschütz, 39**ff., esp 55**:

Eng. translation in Wilson (1978), 235-251. See, too, Symeon Magister Chron. 52 in Bekker, 750, who remarks ca. 962 that of the three youths, only Constantine could see the faint image.

7 Translation drawn from that of A. M. Dubarle, personal correspondence, who plans to publish a French translation of the entire document. See Bulst, 134. Dobschütz, 217*, cites Leon Diaconos (d. 992), whose version of the Abgar legend calls the icon a peplos. He also cites, 189*, John Damascene, de fide 
orthodoxa 4.16, whose account makes it a himation. Gregory's Sermon had been noted but not published by Halkin, vol. 3, 111f., and by Dobschütz, 212*. The 1986 rediscovery of Cod. Vat. Graecus 511 by Italian classicist Gino Zaninotto was presented orally in Rome in 1993.

8 On the Grail's elusiveness, see, e.g., Loomis (1949), 371: "The literature of the Grail amazes us . . by its inconsistency. No Grail romancer agrees with any other and each not infrequently contradicts himself." To my knowledge no scholar has disagreed with this summation. See Malcor, 3341. For numerous references to the icon, see Riant (1875) and Riant (1878).

9 Liturgical Tractate, in Dobschütz $(110 * *-114 * *)$.

10 Gino Zaninotto, "L'Immagine Edessena: Impronta dell'Intera Persone de Cristo. Nuova Conferma del Codex Vossianus Latinus Q69," Proceedings of the Rome Conference on the Turin Shroud (June 1993). Zaninotto considers this 10th c. Latin Abgar text to be a copy of an 8th 9th c. Syriac text; it is virtually identical with the tractatus called the "Oldest Latin Abgar Legend" by Dobschütz, 134**, who saw it in 14th c. Codex Parisiensis B.N. Lat. 6041:

Asserunt autem religiosi plerique viri, qui eum cernere meruerunt, quod in sancto die pasce per diversas se mutare consueverat [a] etatum species, id est ut prima hora diei infantiam, tercia vero puericiam, sexta quoque adulescenciam, nona autem [a]etatis se premonstrat habere plenitudinem, in qua ad passionem dei filius veniens pro nostrorum pondere criminum dirum crucis pertulit supplicium.

Ordericus Vitalis (ca. 1130) in Dobschütz, 224*, and Gervase of Tilbury (ca. 1211), Otia imperialia 3.23 in Dobschütz, 131**ff., similarly refer to the Edessa icon as imprinted with Jesus' entire body (tocius corporis ... statum ). The three texts are remarkably similar to and may derive from a Latin sermon of Pope Stephen at the Lateran Synod of 769, delivered when the cloth was yet in Edessa, and thus describing only a facial image. It may be for this reason that none of the three seems aware that a fult length image on cloth could possibly be a burial-cloth icon. See Wilson (1978), 135, and Dobschütz, 191*. In a related passage (Otia Imperialia 3.24) Gervase knows another imaged cloth which depicted the entire crucif ied body of Jesus and involved Joseph of Arimathia. I suspect the two passages refer to the same imaged icon.

Cum Dominus . . .in cruce penderet, Joseph ab Arimathia ad Mariam matrem Domini . . . O, inquit, [quomodo] quem etiam nudum in cruce pendere vidistis, [sed] non operuistis. . . . Cito euntes emerust linteum mundissimum tam amplum \& extensum, quod tota crucifixi corporis effigies in linteo est expressa....

See this in G. G. Leibnitz, ed. Scriptores Rerum Brunsvicensium et al., 967.

11 Dobschütz, 147**. This and other apocryphal texts, such as the 2nd c. Acta Johannis, involving a polymorphic (child/man) or ephemeral Jesus may have gnostic implications, insinuating a not really human Jesus.

12 Heisenberg, 30.

13 Robert de Clari, Ch. 92. in Hopf, 71:

Et entre ches autres en eut un autre des mousters que on apeloit medame Sainte Marie de Blakerne, ou li sydoines la ou nostres sires fu envelopes, i estoit, qui cascuns desvenres se drechoit tous drois, si que on $i$ pooit bien veir le figure nostre seigneur, ne seut on onques ne Griu ne Franchois que chis sydoines devint, quant le vile fu prise.

McNeal, 112. On Clari's perspicacity see Hopf, 66, and McNeal, 105. Dembrowski is clear that le figure means "entire body," not "face only." My assumption is that the cloth which Clari described in 1203 in the Blachernae Chapel is the same one Mesarites guarded in the Pharos Church in 1201, with hints of an image, and identical with the bloodstained iconic linens named in texts back to Gregory's sermon of 944. A rationale for this is given by Belting (1994), 213; see also Belting (1980-81), 6 ,

n.23.

14 Roberts, VIII. 416ff. Cf. O'Ceallaigh, 56. The Acts of Pilate is a text within the Gospel of Nicodemus. 
15 See O'Gorman, Cabaniss (1954), and Cabaniss (1963). For St. Germanos, see Migne (1865), cols. 387-391. For Honorius, Migne, PL CLXXII, cols. 541ff. Lagorio sees the allegorical tendency already in the In die Parasceves, attributed to St. Ambrose, thus 4th c., where the sepulcher is equated with Mary's womb, both previously unused and immaculate. See Bollandus, VIII, 505. Literal chalices and patens associated with the Last Supper, but not with Joseph of Arimathea, were also claimed in the West. The facts about the marble vas that was sent from Hagia Sophia to Troyes after the Fourth Crusade were confused even in Troyes, despite its Greek rim inscription. The Sagro catino, in Genoa since the First Crusade, was said to be of emerald, but was in fact an emerald-green glass. Valencia's claimed cup was of agate-or of silver and identifiable with the silver cup of the Last Supper seen by Arculfus in Jerusalem in the seventh century. Discussion in Niore'.

16 Maureen Fries, "The Arthurian Moment: History and Geoffrey's Historia regum Britannie," Arthuriana, 8.4 (Winter 1998), 88-99.

17 For Robert, see Nitze (1927), Rogers, Nitze (1953), and le Gentil. Most recently, Burns (1993), xxiii, reminds us that Robert's work is still "the oldest known ancestor text for the [Vulgate] Estoire."

18 James, 158f. Roberts, VIII, 472-476, ascribes the barbaric Latin of the Vindicta Salvatoris to the 7th 8th c. The latter may well be the source of Robert's awareness of the Veronica legends. It is possible, but probably not provable, that the "Oldest Latin Abgar Legend", Ordericus Vitalis, or Gervase of Tilbury (above, n. 10) could have carried the Abgar legend westward to the attention of Robert and his successors. On the other hand, Loomis $(1963,224)$ and others note that the Gospel of Nicodemus was well known in the West. The precise channel by which Robert obtained his Greek material is conjectural and not at issue here.

19 Translated by Loomis (1963), 226. For the French text, see Roach (1949), vol. I, 524-527, w. 1755317671. Loomis, 224ff., and Roach (1966), 162, agree that the passage was written soon after by an interpolator of the First Continuation. Also see Imbs.

20 O'Gorman, "Grail," in Lacy (1986). Molina, 57-63. Much less frequently noted, Helinand also proffered another etymology for the Grail: greal or agreer, signifying that it was pleasing to all. Robert de Boron (vv. 2566-2568) also stated this, leading to the question whether Helinand or Robert was prior. Bruce, I. 254, and Molina, 60, feel Robert was source for Helinand.

21 Loomis (1963), 97. French text in Nitze (1972), vol. I, 23.

22 Nitze, "Perlesvaus", in Loomis (1959), 263-273; Bryant, 19, 26f., and 195f.; French in Nitze (1972), 36ff. and 119ff. Rubin, 135-139.

23 Matarasso, 275f. See Nikolaos Mesarites, in Heisenberg, on the unclothed image on the shroud icon. Zaninotto has cited a key apocryphon, the Acta Johannis (late 2nd c.) in the edition of Junod and Kaestli, 192-195. So nearly does the Grail reflect the tradition of a "polymorphic" Jesus, with its heterodox gnostic associations, that one is tempted to ascribe to this attribute the aversion of the official Roman Church to the Grail (cf. above, n. 11).

24 Loomis (1963), 68, and Roach (1949), II, 516f.: "Sor une aube [ot] tunicle noble D'un chier drap de Costentinoble. Aprés vint grant procession De chanoinnes tout environ, Et chascuns revestuz estoit, Une chape de paile avoit."

25 See Belting (1980-81). Belting (1994), Pl. 207, notes that the Forma pietatis (Man of Pity) arrived in Rome, S. Croce in Gerusalemme, ca. 1380; it is a mosaic icon from Mt. Sinai, but produced in Constantinople ca. 1300. A 12th c. icon from Kastoria may be the earliest: Belting (1980-81), Pl. 3. Also La Favia, 51-60.

26 See Weitzmann and Belting (1981), 96-102 and 124-128.

27 Walter, 205-219 and pl. 55-56. Belting (1981), 124-126. Germanos had intimated the Melismos in the 8th c. Latin translation in Migne (1865), col. 387-391: 
Ita et Dominicum corpus . . . a diacono, ut magna Ecclesia a majoribus accepit, dissecatur ferro quodam quod et lanceam appellant. . . . Ipse vero qui divinum corpus dividit, diaconus, a benedictione angelum imitatur, qui Virgini Ave annuntiavit. Nec mirandum, etiamsi sacerdotes id secent: nam ad consuetudinem magnae Ecclesiae respiciendum. Id igitur dimittitur divinum corpus in prothesi, tanquam in Bethleem, ubi natus est Christus.

For a generous discussion of the Melismos, see Stefanescu, especially illus. LV-LVI and LXVIFLXX. Also Millet (1930), whose essential work on the vision of Peter of Alexandria (d. 311) defines it as a vision of Christ as a boy appearing on the altar during the Mass and complaining of the teachings of Arius. The earliest Greek MS of the 7th c. reached a Latin translation in the 10th c. (This vision should not be confused with that of the Mass of St. Gregory.)

28 Belting (1980-81), 14.

29 The Mass of St. John Chrysostom reflects a long tradition that associated the child in the creche and the crucified Jes us during the Eucharistic service. See Walter, 209-210. That child and crucified are truly one and not illusory may be orthodoxy's response to gnosticism (see above, note 11). Even if these new Byzantine art motifs had nothing in common with the Edessa icon-I think they do-there is good evidence that the Grail romances found an inspiration in the Melismos and processions of the Byzantine Mass.

30 Athos MS No. 69, pp. 154b-164a. Harnack (1901) translated the MS text into German. Editortranslator Kluge (1904), 24-38, thinks this 8th c. MS derives from a 5th c. original. Von Dobschütz (1902) cites Eusebius and Jerome as identifying Lydda with Diospolis. Burdach, 489-494, puts the Georgian MS in the 10th 12th c.

31 On St. Philip in Galatia: Ancient Galatia lay in central Turkey, reaching almost to the Black Sea in the north. Its major cities are Ancyra, Iconium, and Pisidian Antioch bordering on Phrygia. Both Philips are by tradition buried in Hierapolis, a short distance west of first-century Galatia. See discussion in Wesselofsky, 321-325. Christus Druthmarus, monk of Corbei ca. 850, clearly places Philip the disciple in "Galicia" and says he was stoned and crucified in Gerapolis (Hierapolis); but he knows that there was another Philippus deaconus who preached in Samaria. See Migne, PL CVI, col. 1345. In col. 1494 Joseph of Arimathea is named as a rich man decurionae ordine. See Eusebius H.E. III.31.3ff.

32 Duchesne, cii-civ. English translation by L. R. Loomis. It is significant that we read here Britannio and not the expected Britannico. For a response from the pope to Lucius, see Migne, (1894), cols. 11391144 , who considers the response spurious, as no doubt it is.

Anno ab incarnatione Domini CLXVI, M. Antoninus Verus, decimus quartus ab Augusto, regnum cum Aur. Commodo fratre suscepit; quorum temporibus cum Eleutherus vir sanctus Romanae ecclesiae praeesset, misit ad eum Lucius, Britanniarum rex, epistolam, obsecrans ut per eius mandatum christianus efficeretur; et mox effectum piae postulationis consecutus est; susceptamque fidem Britanni usque in tempora Diocletiani principis inviolatam integramque quieta in pace servabant.

In $166 \mathrm{CE}$, when M. Antonius Verus, 14th from Augustus, began to rule with his brother Aur. Commodus, Lucius, king of the Britons, sent a letter to Eleutherus, the head of the Roman church, asking to be made a Christian through his agency. This was soon effected. And the Britons observed their new faith inviolate and whole, quietly in peace, until the rule of Diocletian.

34 For Gildas, see Winterbottom. Bede's preface names many sources, among whom was Nothelm, who searched papal archives in Rome on Bede's behalf. The information of the Liber Pontificalis may thus have reached Bede via Nothelm (suggestion of Rev. Maurus Green in personal correspondence).

35 Freculphus Lexoviensis (Lisieux) Episcopus, Chronicon 2.2.4, in Migne, PL CVI, col. 1148. Freculphus (d. ca. 853) wrote a chronicle from Genesis to Gregory I and the Lombards. He used Josephus, Eusebius, Orosius, Bede, and many others. He seems to have considered the two Philips as the same person. The present paper does not hinge on a choice of Philips. Isidore of Seville (d. ca. 638) had earlier erred in placing Philip in Gaul (Migne, PL, Vol. CVI, Col. 1147ff.). 
36 Robinson, 28. Duchesne, ciii, notes that according to Geoffrey of Monmouth, Historia Regum Britanniae 4:19, the pope sent two men named Faganus and Duvanus. See, too, Lagorio. Robinson shows that the "paper trail" back to Freculphus was first traced by William of Malmesbury in 1125 . Imbs, 70-73, Wesselofsky, and Burdach, 485-488, among others, knew this but did not make the Edessa connections found in this paper. Imbs also points out a Byzantine source of Glastonbury's twin vials of Jesus' blood and water, citing Riant (1878), 212, for a text of 1150, which mentions a single crystal vial of Jesus' blood. See Waite, 333-335, and Malcor, 269-276, on the Legend of Fécamp, in which Joseph of Arimathea scraped blood from Jesus' wounds and collected it in his gauntlet. By miracle and misadventure, the vial of this blood reached Fécamp, the spot marked by a 10th c. monastery.

37 The Vulgate Estoire, using and extending Robert's version, had brought Joseph to Britain as well. Robert's Joseph had hinted twice (vv. 3123 and 3221) that Petrus, of Joseph's group, was destined to go to the "vales of Avaron." Geoffrey of Monmouth had first used insula Avalonis as the place to which Arthur's body was transported. See Geoffrey Ashe, "Avalon," in Lacy (1986). Glastonbury thus claimed to be Avalon in 1191, and Robert may have known this. He was followed by the authors of the Estoire and Perlesvaus. Giraldus Cambrensis (Speculum Ecclesiae, ca. 1215) accepted the Glastonbury claims. The late reference to the grave of Joseph of Arimathea by John of Glastonbury (mid-14th c.) seems negated (or at least antedated) by von Dobschutz (1902), 6, who cites a Syrian-Nestorian chronicle of the 7th c. which asserts that Joseph's grave was discovered in Jerusalem in 605. The Syrian-Nestorian chronicle is dated 670-680. In essence, the text says the Jews asked the Persian general Sahrbaraz for permission to seek under the grave of Jesus for treasure. "When he gave permission and they had dug three els deep, they found a sarcophagus inscribed: This is the sarcophagus of the councilor Joseph, who gave a tomb for the body of Jesus." Even if this text has no merit, Joseph was not buried in Glastonbury. See Wesselofsky and Imbs for the theory that the Lydda legend was used by the Glastonbury monks. Marx has urged that Burgundian Robert de Boron could have had a Glastonbury project in writing his version of the genesis of the Christian Grail. But while claiming Joseph, Glastonbury never clearly claimed to possess the Grail. Burgundian Avalon has been argued as the reality behind Robert's "vales of Avaron" as well. See Giffin.

38 Harnack (1904), 911, cites Lipsius (1884), vol. I, 214, and Zahn, vol. 3, 70.

39 See Hallier, 1, 9, 48-53 and 8491.

40 Zahn cited a text listing the apostles' burial places attributed to the Hypotyposes ("Outlines") of Clement of Alexandria (ca. 150-216), in which we read, "Petrus et Paulus Romae sepulti sunt; . . . Johannes in Epheso; Philippus cum filiabis suis in Hierapoli Asiae; . . . Thaddaeus et Judas [Thomas] in Britio Edessenorum. . . . Clemens in quinto libro hypotyposeon id est informationum." Tixeront quoted the Acta Thaddaei that Thaddaeus died in "Berythe en Phenicia." Though Zahn hesitated in accepting all of the passage, still, on the basis of Zahn (and Clement), Harnack (1904), 913f., effectively resisted Lipsius' and Tixeront's choice of Beirut as the place of Thaddaeus' burial.

41 Entries I and IX of the Chronicle in Hallier, 84 and 91, though authored by a Christian (see entry IV: "In the year 309 [of Seleucus] Our Lord was born."), are unargumentative and apparently unbiased on the issue of when Christianity appeared in Edessa. On this question, see Segal and his bibliography. Also see Runciman, 238-252; Bauer, ch. 1; Tixeront, 68; and Lipsius (1880). Only W. Bauer in Hennecke, vol. I, 439ff., strongly opposes any official establishment of Christianity in Edessa before about 312. He bases his stance on Entry XII of the Edessa Chronicle, which says, "In the year 624 [= 312 ce] Bishop Koinos began construction of the church of Orhai [Edessa]." This must mean a new--and not an "original"--cathedral, as Entry I demands and other scholars accept. Bauer seems to be in a distinct minority on this question.

42 Eusebius H.E. V.3.4 and 23.4. Harnack (1904), 911. Segal does not address the issues of this paper except to note casually $(70, n$. 5) that he disagrees with Harnack's notion that Abgar VIII entered into direct communication with Pope Eleutherus.

43 See Script. Hist. Aug. Sev. 18 for Severus defeating Abgar, who later joined Rome. Herodian III.9.2 puts Abgar on campaign at the side of Severus in 197-198.

44 The key passage for the Roman names of Abgar is Babelon, 247-258, Pls. IV: $2-14$ and V: 1-7, discussed in detail in Bellinger and Welles, 149-151. The evidence for Abgar VIII consists of Greek- 
inscribed bronze coins struck with Commodus, Septimius Severus, and Caracalla. These coins of Abgar VIII (dating from 177 to 211) testify to his close relations with Rome, emphasized by his assuming the names Lucius Aelius Aurelius Septimius, which appear on the coins themselves.

45 See Dio Cass, Epitome of Bk. 80.16, for Abgar's visit to Rome Segal, 14, n. 1, notes that Abgar VIII (177-212) is wrongly called IX, as Bellinger and Welles, 150, prove. Abgar IX (212-214) did, however, take the name Severus.

46 See Harnack (1901), 923. The same 8th c. Georgian MS, concerning the founding of a church in honor of Mary in Lydda by Philip and Joseph, may well be a long-lost original of a Latin document discussed among the apocrypha as the "I, Joseph," and usually given a 12th c. date. Both hereby gain greatly in importance.

\section{BIBLIOGRAPHY}

Abrams, Lesley and James E. Carley, eds. The Archaeology and History of Glastonbury Abbey (Woodbridge, U.K., and Rochester, N.Y.: Boydell Pr., 1991).

Belting, Hans. Likeness and Presence: A History of the Image Before the Era of Art Chicago: Univ. of Chica go Pr., 1994).

Hennecke, Edgar. New Testament Apocrypha. Wilhelm Schneemelcher, ed.; R. M. Wilson, tr. 2 vols. (Philadelphia: Westminster, 1963).

Lacy, Norris, ed. The Arthurian Encyclopedia (New York: Garland, 1986).

Lagorio, Valerie M. The Evolving Legend of St Joseph of Glastonbury. Speculum XLVI, 2 (April 1971): 209-231.

Robinson, J. A. Two Glastonbury Legends: King Arthur and St Joseph of Arimathea (Cambridge: Cambridge Univ. Pr., 1926).

Rogers, Jean, tr. Joseph of Arimathea: A Romance of the Grail (London: Steiner, 1990). 